\title{
Productivity of BT and Non BT Cotton (Gossypium hirsutum L.) Cultivars as Influenced by Plant Geometry and Fertilizer Levels
}

\author{
T. Nagender*, D. Raji Reddy, P. Leela Rani, G. Sreenivas, K. Surekha, \\ Akhilesh Gupta and P.D. Sreekanth \\ Department of Agronomy, PJTSAU, Rajendranagar, Hyderabad-500 030, Telangana, India \\ *Corresponding author
}

\section{A B S T R A C T}

\begin{tabular}{|l|}
\hline K e y w o r d s \\
Bt cotton, Nitrogen, \\
Monopodia, \\
Sympodia, \\
Seed cotton yield, \\
Plant density. \\
\hline Article Info \\
\hline $\begin{array}{l}\text { Accepted: } \\
\text { 28 August } 2017 \\
\text { Available Online: } \\
\text { 10 September } 2017\end{array}$ \\
\hline
\end{tabular}

A field experiment was conducted during 2015-16 and 2016-17 at Hyderabad to assess the performance of two cotton hybrids of which Bt (MRC 7201 BGII) and non-Bt cotton (WGCV-48) in response to plant densities $\left(\mathrm{P}_{1}: 18,518\right.$ plants ha ${ }^{-1}, \mathrm{P}_{2}: 55,555$ plants ha ${ }^{-1}$ and $\mathrm{P}_{3}: 1,48,148$ plants $\left.\mathrm{ha}^{-1}\right)$ and nitrogen fertilization $\left(120,150\right.$ and $\left.180 \mathrm{~kg} \mathrm{ha}^{-1}\right)$. During 2015 and 2016, MRC 7201 BG II cultivar recorded significantly more plant height (125.0 $\mathrm{cm}$ and $141.4 \mathrm{~cm}), \mathrm{LAI}(5.23$ and 4.95$)$ and dry matter production $\left(246 \mathrm{~g} \mathrm{plant}^{-1}\right.$ and $241 \mathrm{~g}$ plant $\left.^{-1}\right)$, number of sympodial branches plant ${ }^{-1}(42,40)$ and kapas yield $\left(3497,2866 \mathrm{~kg} \mathrm{ha}^{-1}\right)$ in comparison to WGCV-48 cultivar, respectively. Plant density $\mathrm{P}_{1}\left(18,518\right.$ plants ha ${ }^{-1)}$ at $90 \mathrm{~cm}$ x $60 \mathrm{~cm}$ spacing recorded significantly more dry matter production $\left(301 \mathrm{~g} \mathrm{plant}^{-1}\right.$, 298 g plant $\left.^{-1}\right)$ over $\mathrm{P}_{2}\left(55,555\right.$ plants ha $\left.^{-1}\right)$ at $60 \mathrm{~cm} \mathrm{x} 30 \mathrm{~cm}$ and $\mathrm{P}_{3}\left(1,48,148\right.$ plants ha $\left.{ }^{-1}\right) 45$ cm x $15 \mathrm{~cm}$ spacing during 2015 and 2016 respectively. During 2015 and 2016, among the plant densities, even though the plant density of $\mathrm{P}_{1}$ : 18,518 plants ha $^{-1}$ showed more number of sympodial branches plant ${ }^{-1}(55,53)$ and kapas yield plant ${ }^{-1}(149,122)$, but the plant density of $\mathrm{P}_{2}: 55,555$ plants ha ${ }^{-1}$ significantly more kapas yield $\left(3319,2726 \mathrm{~kg} \mathrm{ha}^{-1}\right)$.

\section{Introduction}

Cotton is a natural part of everyday life which serves the mankind from the cradle to the grave. Cotton plays a key role in socioeconomic and political affairs of the world (Kairon et al., 2004). Its production, processing and trade generate revenue and sustain livelihoods in many countries. It is the world's leading source of natural textile fiber and fifth largest oilseeds crop which covers $40 \%$ of the global textile need (APTMA, 2012) and $3.3 \%$ of edible oil (FAS, 2014), respectively. Cotton is the most important commercial and premier cash crop of India. It plays a prominent role in farming and industrial economy of the country.
With the introduction of Bt cotton hybrids, there has been a significant change in the cotton cultivation scenario of India. Now, around 40 per cent area under cotton is occupied by Bt cotton hybrids. However, the average production is very low when compared to world's average. This is mainly because 70 per cent of cotton area is under rainfed condition.

Cotton (Gossypium hirsutum L.) crop assumes a place of special significance in Indian economy. India is the only country in the world which grows four types of cultivated species of cotton. During the last 
decade, a decline in seed cotton yield was observed due to severe incidence of boll worms which resulted in decrease in cotton area. However, after the introduction of $\mathrm{Bt}$ cotton which resists the boll worm attack in 2002, the technology has been widely accepted by Indians and the area under cotton increased to 11.64 million ha with a production of 33.4 million bales with productivity of $489 \mathrm{~kg} \mathrm{ha}^{-1}$ in 2012-13 (Anonymous, 2013). Now 90 per cent of cotton area was occupied by Bt cotton. By adopting appropriate agronomic practices cotton yield per unit area can be improved. Management decisions like variety selection, planting date, plant density, and nitrogen management have a profound effect on the development and final outcome of the crop.

Till date, there is confusion in the farming community that whether Bt crop needs same plant geometry and nutrient requirement as that of non Bt cotton. Vegetative growth in $\mathrm{Bt}$ cotton is restricted due to $100 \%$ setting of fruiting bodies on the plant, which requires closer spacing for better yields. Chen et al., (2004) specified the need to develop agronomic management practices as there are changes in vegetative and reproductive characteristics of $\mathrm{Bt}$ cotton. Lack of knowledge about important agronomical practices could also be another reason. So, there is a need to identify suitable Bt cotton genotype which gives higher net returns with lower cost of cultivation. Keeping this in view the present study was carried out to find the optimum spacing and nitrogen requirement for $\mathrm{Bt}$ and non $\mathrm{Bt}$ cotton under rainfed conditions.

\section{Materials and Methods}

These investigations were carried out during Kharif 2015-16 and 2016-17 at Agricultural Research Institute, Rajendranagar, Hyderabad situated at an altitude of $542.3 \mathrm{~m}$ above mean sea level at $17^{\circ} 19^{\prime} \mathrm{N}$ latitude and $78^{\circ} 23^{\prime} \mathrm{E}$ longitude. It is in the Southern Telangana agro-climatic zone of Telangana. According to Troll's climatic classification, it falls under semi-arid tropics (SAT). The experiment was laid out in randomized block design (factorial) replicated thrice with two cultivars (MRC 7201 BG II, WGCV-48) three plant densities $\left(\mathrm{P}_{1}\right.$ : 18,518 plants ha $^{-1} \mathrm{P}_{2}$ : 55,555 plants ha ${ }^{-1} \mathrm{P}_{3}$ : $1,48,148$ plants $\left.\mathrm{ha}^{-1}\right)$ and three nitrogen levels $\left(\mathrm{N}_{1}: 120 \mathrm{~kg} \mathrm{ha}^{-1}, \mathrm{~N}_{2}: 150 \mathrm{~kg}\right.$ $\left.\mathrm{ha}^{-1}, \mathrm{~N}_{3}: 180 \mathrm{~kg} \mathrm{ha}^{-1}\right)$. The soil of the experimental site was sandy loam in texture, neutral in reaction, low in available nitrogen, phosphorus and high in available potassium. During the crop period rainfall of $375.3 \mathrm{~mm}$ was received in 27 rainy days in first year and $740.9 \mathrm{~mm}$ in 37 rainy days in second year, respectively as against the decennial average of $616.2 \mathrm{~mm}$ received in 37 rainy days for the corresponding period indicating 2016-17 as wet year comparatively.

Field was ploughed once with tractor drawn mould board plough followed by cultivator and later with disc harrow. The land within each plot was leveled in order to maintain uniform irrigation water application. Cotton crop was sown on July 8, 2015 and July 7, 2016 by dibbling seeds in opened holes with a hand hoe at depth of 4 to $5 \mathrm{~cm}$ as per the spacing in treatments viz., $90 \mathrm{~cm}$ X $60 \mathrm{~cm}, 60$ $\mathrm{cm} \mathrm{X} 30 \mathrm{~cm}$ and $45 \mathrm{~cm} \mathrm{X} 15 \mathrm{~cm}$. A uniform dose of $60 \mathrm{~kg} \mathrm{ha}^{-1} \mathrm{P}_{2} \mathrm{O}_{5}$ as single super phosphate, potassium @ $60 \mathrm{~kg} \mathrm{ha}^{-1}$ as muriate of potash was applied to all the treatments of Bt cotton cultivar. Entire dose of phosphorus was applied as basal at the time of sowing. Nitrogen was applied as per the treatments (wherever it was required) in the form of urea $(46 \% \mathrm{~N})$ in four equal splits $(20,40,60$ and 80 days after sowing (DAS). Similarly, the remaining potassium was applied along with urea in four splits at 20, 40, 60 and 80 days after sowing (DAS) respectively. Whereas, for non Bt cotton cultivar uniform dose of 45 
$\mathrm{kg} \mathrm{ha}^{-1} \mathrm{P}_{2} \mathrm{O}_{5}$ as single super phosphate, potassium@45 kg ha ${ }^{-1}$ as muriate of potash was applied to all the treatments. Entire dose of phosphorus was applied as basal at the time of sowing. Nitrogen was applied as per the treatments (wherever it was required) in the form of urea $(46 \% \mathrm{~N})$ in three equal splits (30, 60 and 90 days after sowing (DAS). Similarly, the remaining potassium was applied along with urea in 3 splits at 30,60 and 90 days after sowing (DAS) respectively.

Pre emergence herbicide pendimethalin @ 2.5 $\mathrm{ml} \mathrm{l}^{-1}$ was sprayed to prevent growth of weeds. Post emergence spray of quizalofop ethyl 5\% EC @ $2 \mathrm{ml} \mathrm{l}^{-1}$ and pyrithiobac sodium 10\% EC @ $1 \mathrm{ml} \mathrm{l}^{-1}$. Hand weeding was carried out once at 35 DAS. First irrigation was given immediately after sowing of the crop to ensure proper and uniform germination. Later irrigations were scheduled uniformly by adopting climatological approach i.e., IW/CPE ratio of 0.80 at $5 \mathrm{~cm}$ depth.

During crop growing season sucking pest incidence was noticed. Initially at 25 DAS spraying of monocrotophos @ $1.6 \mathrm{ml} \mathrm{l}^{-1}$ was done. During later stages, acephate @ $1.5 \mathrm{~g} \mathrm{l}^{-1}$ and fipronil @ $2 \mathrm{ml} \mathrm{l}^{-1}$ were sprayed alternatively against white fly and other sucking pests complex during the crop growth period as and when required. For controlling boll worms in non Bt cultivar, monocrotophos @ $1.6 \mathrm{ml} \mathrm{l}^{-1}$ and emamectin benzoate $5 \% \mathrm{SG}$ @ $0.5 \mathrm{~g} \mathrm{l}^{-1}$ was sprayed based on the infestation whenever required.

Plant height from the first cotyledon node to the top most growing point was measured in $\mathrm{cm}$ at square initiation, first flowering, first boll formation, boll development, first boll bursting and first picking stages with a linear meter scale. The representative plants were destructively sampled from each plot at square initiation, first flowering, first boll formation, boll development, first boll bursting and first picking stages by cutting at the base. The plants were initially dried in the shade then cut in to pieces and transferred to labeled brown paper bags and later kept in a hot air oven at $74^{\circ} \mathrm{C}$ the weight of the oven dried plants was recorded and the mean value was recorded as the dry matter accumulation plant ${ }^{-1}$ of cotton. The monopodial branch is an exact replica of the main stem.

These branches are formed at the base of the plant and do not bear flowers and bolls directly. Fruiting bodies are formed on further branches of monopodia. These were counted from labeled plants at flowering and monopodia plant ${ }^{-1}$ was worked out. The branches formed above the growing shoots inside the axis of $4^{\text {th }}$ or $5^{\text {th }}$ leaf which bear flowers at each node and grow horizontally are called sympodials. These were counted from labeled plants at flowering, boll development and first picking stages were worked out.

Leaf area index was measured at square formation, flowering and boll development with leaf area meter (LICOR model LI-3000) and expressed in $\mathrm{cm}^{2}$ plant $^{-1}$ (Watson, 1957).

$$
\text { LAI }=\frac{\text { Leaf area plant }}{-1}
$$

The cumulative yield of seed cotton from each picking in each treatment from net plot was weighed and expressed in $\mathrm{kg} \mathrm{ha}^{-1}$. Data on different characters viz., growth and yield components and yield, were subjected to analysis of variance procedures as outlined for randomized block design, factorial concept (Gomez and Gomez, 1984). Statistical significance was tested by $\mathrm{F}-$ value at 0.05 level of probability and critical difference was worked out wherever the effects were significant. 


\section{Results and Discussion}

\section{Effect of plant densities}

The plant height was higher with $\mathrm{P}_{2}: 60 \mathrm{~cm} \mathrm{x}$ $30 \mathrm{~cm}$ at first picking $(131.7 \mathrm{~cm}, 141.2 \mathrm{~cm})$ in 2015 and 2016 respectively. Morphological changes in plants are induced when plant density is increased mainly because of competition for light when soil fertility and moisture are not limited increased plant density results in mutual shading of plants which usually results in stem elongation. The taller plants at higher plant density late in the season might be due to inter plant competition for nutrients and light. Further the availability of horizontal space for individual plant at closer spacing reduced, due to which intense inter plant competition for nutrient and light suppressed node appearance and plants grew taller in respect of vertical space (Wang et al., 2011).

In 2015 and 2016, the highest LAI was observed in $\mathrm{P}_{3}: 45 \mathrm{~cm} \times 15 \mathrm{~cm}$ (148148 plants $\left.\mathrm{ha}^{-1}\right)$ at boll development $(5.06,6.02)$ and significantly superior to $\mathrm{P}_{2}: 60 \mathrm{~cm} \times 30 \mathrm{~cm}$ (55555 plants $\mathrm{ha}^{-1}$ ) and $\mathrm{P}_{1}: 90 \mathrm{~cm} \mathrm{x} 60 \mathrm{~cm}$ (18518 plants ha ${ }^{-1}$ ) which recorded the lowest leaf area index values, at boll development $(3.98,3.83)$ stages respectively in both the years. Per cent increase in maximum LAI at boll development stage for $\mathrm{P}_{3}$ over $\mathrm{P}_{2}$ and $\mathrm{P}_{1}$ were $8,25 \%$ and $21,36 \%$ during 2015 and 2016 respectively. Higher values of LAI with higher plant densities may be ascribed to the more plant stand coupled with taller plants achieving more leaves thus having more LAI. These results were supported by the findings of Manjunatha et al., (2010).

In 2015 and 2016 significantly more dry matter accumulation plant ${ }^{-1}$ was observed in $\mathrm{P}_{1}: 90 \mathrm{~cm} \times 60 \mathrm{~cm}\left(18518\right.$ plants $\left.\mathrm{ha}^{-1}\right)$ at first picking (301, $298 \mathrm{~g} \mathrm{plant}^{-1}$ ) and significantly superior to $\mathrm{P}_{2}: 60 \mathrm{~cm} \times 30 \mathrm{~cm}(55555$ plants $\mathrm{ha}^{-1}$ ) and $\mathrm{P}_{3}: 45 \mathrm{~cm} \mathrm{x} 15 \mathrm{~cm}$ (148148 plants $\left.\mathrm{ha}^{-1}\right)$. Lowest dry matter accumulation plant ${ }^{-1}$ was observed in $\mathrm{P}_{3}: 45 \mathrm{~cm} \times 15 \mathrm{~cm}$ at first picking $\left(184,160 \mathrm{~g} \mathrm{plant}^{-1}\right)$. The per cent increase in dry matter production for $\mathrm{P}_{1}$ over $\mathrm{P}_{2}$ and $\mathrm{P}_{3}$ at first picking was 23, $21 \%$ and 50, $59 \%$ during 2015 and 2016 respectively (Table 1). Dry matter plant ${ }^{-1}$ was higher with wider spacing, this might be due to more canopy development under wider spacing (Devraj et al., 2011). The marked improvements in growth and yield attributing character was brought due to the more availability of solar radiation and that helps to synthesis and partitioning of assimilates to individual plant under wider spacing, which ultimately translocate assimilates from source to sink that leads to significant increment in growth attributes in respect of dry matter of plant (Bhalerao et al., 2008 and Madhavi, 2016).

During the both years of investigation, significantly more no. of monopodial branches plant ${ }^{-1}$ was observed in $\mathrm{P}_{1}$ : $90 \mathrm{~cm} \mathrm{x}$ $60 \mathrm{~cm}\left(18518\right.$ plants $\left.\mathrm{ha}^{-1}\right)(4,4)$ and significantly superior to $\mathrm{P}_{2}: 60 \mathrm{~cm} \times 30 \mathrm{~cm}$ $\left(55555\right.$ plants ha $\left.{ }^{-1}\right)(3,3)$ and $\mathrm{P}_{3}: 45 \mathrm{~cm} \mathrm{x} 15$ cm $\left(148148\right.$ plants ha $\left.^{-1}\right)(1,1)$ respectively at flowering stage (Table 2). The observations are in confirmity with Reddy and Gopinath (2008) and Jadhav et al., (2015).

In 2015 and 2016, the highest no. of sympodial branches plant ${ }^{-1}$ was observed in $\mathrm{P}_{1}: 90 \mathrm{~cm} \times 60 \mathrm{~cm}\left(18518\right.$ plants ha $\left.{ }^{-1}\right)$ at first picking $(55,53)$ and significantly superior to $\mathrm{P}_{2}: 60 \mathrm{~cm} \mathrm{x} 30 \mathrm{~cm}$ (55555 plants ha $\left.{ }^{-1}\right)$ and $\mathrm{P}_{3}$ : $45 \mathrm{~cm} \mathrm{x} 15 \mathrm{~cm}$ (148148 plants ha $\left.{ }^{-1}\right)$ which recorded the lowest no. of sympodial branches plant ${ }^{-1}$, at first picking $(21,20)$ stages respectively (Table 2). Per cent increase in no. of sympodial branches plant ${ }^{-1}$ at first picking stage for $\mathrm{P}_{1}$ over $\mathrm{P}_{2}$ and $\mathrm{P}_{3}$ were 28, $28 \%$ and 61, $62 \%$ during 2015 and 2016 respectively. 
Table.1 Plant height $(\mathrm{cm})$, LAI, dry matter $\left(\mathrm{g}_{\text {plant }}{ }^{-1}\right)$ production cotton as influenced by cultivars, plant densities and nitrogen levels

\begin{tabular}{|c|c|c|c|c|c|c|}
\hline \multirow{3}{*}{ Treatments } & \multicolumn{2}{|c|}{ Plant height $(\mathrm{cm})$} & \multicolumn{2}{|l|}{ LAI } & \multicolumn{2}{|c|}{ Dry matter $\left(\right.$ g plant $\left.^{-1}\right)$} \\
\hline & \multicolumn{2}{|c|}{ Boll development } & \multicolumn{2}{|c|}{$1^{\text {st }}$ picking } & \multicolumn{2}{|c|}{$1^{\text {st }}$ picking } \\
\hline & 2015 & 2016 & 2015 & 2016 & 2015 & 2016 \\
\hline \multicolumn{7}{|l|}{ Factor 1 (Cultivars) } \\
\hline $\mathrm{V}_{1}(\mathrm{MRC} 7201 \mathrm{BGII})$ & 125.0 & 141.4 & 5.23 & 4.95 & 246 & 241 \\
\hline $\mathrm{V}_{2}(\mathrm{WGCV}-48)$ & 120.0 & 131.1 & 3.90 & 4.60 & 231 & 219 \\
\hline S.Em \pm & 1.7 & 2.0 & 0.13 & 0.09 & 4.0 & 7.3 \\
\hline $\mathrm{CD}(\mathrm{P}=\mathbf{0 . 0 5})$ & 4.8 & 5.7 & 0.38 & 0.27 & 11.6 & 21.1 \\
\hline \multicolumn{7}{|c|}{ Factor 2 (Plant densities) } \\
\hline$P_{1}(90 \mathrm{~cm} X 60 \mathrm{~cm})$ & 120.3 & 132.8 & 3.98 & 3.83 & 301 & 298 \\
\hline$P_{2}(60 \mathrm{cmX30} \mathrm{cm})$ & 131.2 & 141.2 & 4.64 & 4.48 & 231 & 233 \\
\hline$P_{3}(45 \mathrm{cmX} 15 \mathrm{~cm})$ & 116.0 & 134.6 & 5.06 & 6.02 & 184 & 160 \\
\hline S.Em \pm & 2.0 & 2.4 & 0.16 & 0.11 & 5.0 & 9.0 \\
\hline $\mathrm{CD}(\mathrm{P}=\mathbf{0 . 0 5})$ & 5.9 & 7.0 & 0.47 & 0.33 & 14.2 & 25.8 \\
\hline \multicolumn{7}{|c|}{ Factor 3 (Nitrogen levels) } \\
\hline$N_{1}\left(120\right.$ kg N ha $\left.{ }^{-1}\right)$ & 121.3 & 138.8 & 4.37 & 4.74 & 244 & 241 \\
\hline$N_{2}\left(150 \mathrm{~kg} \mathrm{~N} \mathrm{ha}^{-1}\right)$ & 121.9 & 132.4 & 4.53 & 4.82 & 237 & 226 \\
\hline $\mathrm{N}_{3}\left(180 \mathrm{~kg} \mathrm{~N} \mathrm{ha}^{-1}\right)$ & 124.4 & 137.4 & 4.79 & 4.77 & 235 & 223 \\
\hline S.Em \pm & 2.0 & 2.4 & 0.16 & 0.11 & 5.0 & 9.0 \\
\hline $\mathrm{CD}(\mathrm{P}=\mathbf{0 . 0 5})$ & NS & NS & NS & NS & NS & NS \\
\hline
\end{tabular}


Table.2 Monopodial, sympodial branches and seed cotton yield $\left(\mathrm{kg} \mathrm{ha}^{-1}\right)$ of cotton as influenced by cultivars, Plant densities and nitrogen levels

\begin{tabular}{|c|c|c|c|c|c|c|}
\hline \multirow[t]{3}{*}{ Treatments } & \multirow{2}{*}{\multicolumn{2}{|c|}{$\begin{array}{l}\text { Monopodial branches } \\
\left(\text { No. } \text { plant }^{-1}\right) \\
\text { Flowering } \\
\end{array}$}} & \multirow{2}{*}{\multicolumn{2}{|c|}{$\begin{array}{l}\text { Sympodial branches } \\
\left(\text { No. } \text { plant }^{-1}\right) \\
\mathbf{1}^{\text {st }} \text { picking } \\
\end{array}$}} & \multirow{2}{*}{\multicolumn{2}{|c|}{ Seed cotton yield $\left(\mathrm{kg} \mathrm{ha}^{-1}\right)$}} \\
\hline & & & & & & \\
\hline & 2015 & 2016 & 2015 & 2016 & 2015 & 2016 \\
\hline \multicolumn{7}{|l|}{ Factor 1 (Cultivars) } \\
\hline $\mathrm{V}_{1}(\mathrm{MRC} 7201$ BGII) & 2 & 2 & 42 & 40 & 3497 & 2866 \\
\hline $\mathrm{V}_{2}(\mathrm{WGCV}-48)$ & 3 & 3 & 35 & 34 & 2510 & 2078 \\
\hline S.Em \pm & 0.06 & 0.06 & 0.44 & 0.33 & 74 & 49 \\
\hline $\mathrm{CD}(\mathrm{P}=\mathbf{0 . 0 5})$ & 0.18 & 0.16 & 1.25 & 0.96 & 214 & 141 \\
\hline \multicolumn{7}{|c|}{ Factor 2 (Plant densities) } \\
\hline$P_{1}(90 \mathrm{~cm} X 60 \mathrm{~cm})$ & 4 & 3 & 55 & 53 & 2738 & 2309 \\
\hline$P_{2}(60 \mathrm{cmX30} \mathrm{cm})$ & 3 & 3 & 39 & 38 & 3319 & 2726 \\
\hline$P_{3}(45 \mathrm{cmX} 15 \mathrm{~cm})$ & 1 & 1 & 21 & 20 & 2954 & 2381 \\
\hline S.Em \pm & 0.08 & 0.07 & 0.53 & 0.41 & 91 & 60 \\
\hline $\mathrm{CD}(\mathrm{P}=\mathbf{0 . 0 5})$ & 0.22 & 0.20 & 1.53 & 1.18 & 261 & 173 \\
\hline \multicolumn{7}{|c|}{ Factor 3 (Nitrogen levels) } \\
\hline $\mathrm{N}_{1}\left(120 \mathrm{~kg} \mathrm{~N} \mathrm{ha} \mathbf{p}^{-1}\right)$ & 3 & 2 & 38 & 37 & 2946 & 2383 \\
\hline$N_{2}\left(150\right.$ kg $\left.N h^{-1}\right)$ & 3 & 2 & 38 & 37 & 2962 & 2528 \\
\hline$N_{3}\left(180\right.$ kg $\left.N h^{-1}\right)$ & 3 & 3 & 39 & 37 & 3102 & 2505 \\
\hline S.Em \pm & 0.08 & 0.07 & 0.53 & 0.41 & 91 & 60 \\
\hline $\mathrm{CD}(\mathrm{P}=\mathbf{0 . 0 5})$ & NS & NS & NS & NS & NS & NS \\
\hline
\end{tabular}


The increase in number of sympodia in wider intra spacing and inter row spacing $\mathrm{P}_{1}: 90 \mathrm{~cm}$ x $60 \mathrm{~cm}$ (18518 plants ha $\left.{ }^{-1}\right)$ was mainly due to availability of adequate amount of nutrients, moisture and light interception for optimum growth and development leading to production of more number of sympodia.

Availability of space for lateral expanding of branches and chance to enhance auxiliary buds of plant as compared to closer plant and row spacing recorded more competition for space, light and nutrient. These observations are in conformity with Bhalerao et al., (2008) and Kalaichelvi (2008).

Significantly higher seed cotton yield (3319 and $2726 \mathrm{~kg} \mathrm{ha}^{-1}$ ) was obtained in $\mathrm{P}_{2}: 60 \mathrm{~cm} \mathrm{x}$ $30 \mathrm{~cm}$ (55555 plants ha ${ }^{-1}$ ) over $\mathrm{P}_{3}: 45 \mathrm{~cm} \mathrm{x} 15$ cm (148148 plants $\mathrm{ha}^{-1}$ ) and $\mathrm{P}_{1}: 90 \mathrm{~cm} \mathrm{x} 60$ cm (18518 plants ha ${ }^{-1}$ ), while $\mathrm{P}_{3}$ (2954 and $\left.2381 \mathrm{~kg} \mathrm{ha}^{-1}\right)$ and $\mathrm{P}_{1}\left(2738\right.$ and $\left.2309 \mathrm{~kg} \mathrm{ha}^{-1}\right)$ are comparable and on par with each other (Table 2). The per cent increase of seed cotton yield in $\mathrm{P}_{2} 11,13 \%$ and $17,15 \%$ during 2015 and 2016 over $\mathrm{P}_{3}$ and $\mathrm{P}_{1}$ respectively.

The ultimate seed cotton yield is the manifestation of yield contributing characters. These yield attributing characters were significantly affected by different plant populations. Even though, the boll number, boll weight and seed cotton yield plant ${ }^{-1}$ were significantly higher with wider spacing, it could not compensate for the loss in number of plants $\mathrm{ha}^{-1}$ and number of bolls $\mathrm{m}^{-2}$, thus recorded lower seed cotton yield ha ${ }^{-1}$ when compared to high density planting.

Higher plant density at closer spacing recorded significantly higher seed cotton yield than lower plant density at wider spacing due to significantly more number of bolls $\mathrm{m}^{-2}$ and higher plant stand $\mathrm{ha}^{-1}$ (Kalaichelvi, 2009, Krishnaveni et al., (2010), Manjunatha et al., (2010) and Brar et al., 2013).

\section{Effect of Bt gene}

In 2015, higher plant height was observed in MRC 7201 BGII cultivar $(125.0 \mathrm{~cm})$ which was significantly superior to WGCV-48 (Table 1). In 2016, maximum plant height $(141.4 \mathrm{~cm})$ was recorded with MRC 7201 BGII cultivar at first picking stages and was significantly superior to WGCV-48, which recorded the lowest plant height at first picking $(131.1 \mathrm{~cm})$. The probable reason for this might be the variation in the genetic constitution of the cultivars which has responded better in plant height. These results were in closer conformity with the findings of Manjunatha et al., (2010) and Gangaiah et al., (2013).

In 2015 and 2016, maximum LAI was observed in MRC 7201 BGII cultivar at boll development $(5.23,4.95)$ and significantly superior to WGCV-48 cultivar at boll development $(3.90,4.60)$ respectively (Table 1). The reduction in maximum LAI for WGCV-48 cultivar was 22 and $7 \%$ over MRC 7201 BGII cultivar during 2015 and 2016 respectively at boll development stage. The increased LAI in MRC 7201 BGII cultivar might be due to increased plant height. These results were in close agreement with the findings of Manjunatha et al., (2010).

MRC 7201 BGII cultivar was significantly superior in dry matter plant ${ }^{-1}$ at first picking $\left(246,241 \mathrm{~g} \mathrm{plant}^{-1}\right)$ to WGCV-48 (Table 1). The per cent increase in dry matter production of MRC 7201 BGII over WGCV-48 was 5, 9 $\%$ during 2015 and 2016 respectively at first picking.

Higher dry matter production per plant pertaining to MRC 7201 BGII cultivar may be attributed to the improvement in the assimilation of photosynthates and their accumulation in leaves, stem and reproductive parts at various stages of crop growth. These 
results were in close agreement with findings of Manjunatha et al., (2010) and Shukla et al., (2013).

WGCV-48 cultivar was significantly superior in no. of monopodial branches plant ${ }^{-1}(3,3)$ to MRC 7201 BGII cultivar $(2,2)$ during both years respectively at flowering stage (Table 2 ). The probable reason of this might be the variation in the genetic constitution of the cultivars which has responded higher number of monopodial branches plant ${ }^{-1}$ in WGCV-48 cultivar then MRC 7201 BGII cultivar. These results are in closer conformity with the findings of Aruna et al., (2016).

No. of sympodial branches plant ${ }^{-1}$ steadily increased and reached at maximum value at first picking in 2015 and 2016 for MRC 7201 BGII and WGCV-48 cultivars (Table 2). In 2015 and 2016, maximum no. of sympodial branches plant ${ }^{-1}$ was observed in MRC 7201 BGII cultivar at first picking $(42,40)$ and significantly superior to WGCV-48 cultivar at first picking $(35,34)$ respectively. The reduction in maximum no. of sympodial branches for WGCV-48 cultivar was 17 and $16 \%$ over MRC 7201 BGII cultivar during 2015 and 2016 respectively at first picking stage. Branching is a genetically governed trait until and unless there are abrupt changes in the environment and reduced number of nodes resulting in reduction of sympodia plant $^{-1}$. These findings are in agreement with the results reported by Manjunatha et al., (2010).

The response due to variation in cultivars was similar in both years of study. The highest seed cotton yield (3497 and $2866 \mathrm{~kg} \mathrm{ha}^{-1}$ ) was obtained with MRC 7201 BGII cultivar and was significantly superior to WGCV-48 cultivar $\left(2560\right.$ and $\left.2078 \mathrm{~kg} \mathrm{ha}^{-1}\right)$. The rate of increase in seed cotton yield with $\mathrm{V}_{1}$ was 28 and $27 \%$ during 2015 and 2016 over $V_{2}$ respectively (Table 2). Higher seed cotton yield was evidently due to cumulative effect of more number of bolls/plant and boll weight in $\mathrm{Bt}$ hybrid than non Bt. The better performance of MRC 7201 BGII cultivar over WGCV-48 cultivar was ascribed to higher boll numbers plant ${ }^{-1}$ and heavier boll weight and the superior performance of $\mathrm{Bt}$ hybrids might be also due to inbuilt resistance to boll worms by $\mathrm{Bt}$ gene which in turn might have caused Bt hybrids to move in to reproductive phase early by curtailing vegetative growth and helped to produce higher seed cotton yield (Aruna, 2016).

\section{Effect of nitrogen levels}

Nitrogen levels did not show any significant influence on plant height, LAI, dry matter production, no. of monopodial branches plant ${ }^{1}$, no. of sympodial branches plant ${ }^{-1}$ and kapas yield $\left(\mathrm{kg} \mathrm{ha}^{-1}\right)$ at all growth stages of cotton crop during 2015 and 2016 (Tables 1 and 2). These results were substantiated by the findings of Aruna (2016) and Sankaranarayanan et al., (2011).

\section{Interaction effect}

Interactions between cultivars and plant densities, plant densities and nitrogen levels, cultivars and nitrogen levels, and cultivars, plant densities and nitrogen levels were not found statistically significant at any stage of the crop growth during both years for plant height, LAI, dry matter production, no. of monopodial branches plant $^{-1}$, no. of sympodial branches plant ${ }^{-1}$ and kapas yield $\left(\mathrm{kg} \mathrm{ha}^{-1}\right)$.

During 2015 and 2016, MRC 7201 BG II cultivar recorded significantly more plant height, LAI, number of monopodial branches plant $^{-1}$, number of sympodial branches plant ${ }^{-1}$ and kapas yield in comparison to WGCV-48 cultivar, respectively. Plant density $\mathrm{P}_{1}(18,518$ plants $\mathrm{ha}^{-1}$ ) at $90 \mathrm{~cm}$ x $60 \mathrm{~cm}$ spacing 
recorded significantly more dry matter production over $\mathrm{P}_{2}\left(55,555\right.$ plants $\left.\mathrm{ha}^{-1}\right)$ at 60 $\mathrm{cm} \times 30 \mathrm{~cm}$ and $\mathrm{P}_{3}\left(1,48,148\right.$ plants ha $\left.{ }^{-1}\right) 45$ $\mathrm{cm}$ x $15 \mathrm{~cm}$ spacing during 2015 and 2016 respectively. During 2015 and 2016, among the plant densities, even though the plant density of $\mathrm{P}_{1}$ : 18,518 plants $\mathrm{ha}^{-1}$ showed more number of sympodial branches plant $^{-1}$ and kapas yield plant ${ }^{-1}$ but the plant density of $\mathrm{P}_{2}$ : 55,555 plants ha $^{-1}$ significantly more kapas yield.

\section{References}

Anonymous, 2010. Report on Area, production and productivity of cotton. Cotton Advisory Board, Government of India.

APTMA, 2012. World Cotton and non-Cotton Fiber Consumption. Available online at http://www.aptma.org.pk/Pak_Textile_ Statistics/ repo.asp.

Aruna, E., 2016. Productivity and quality of Bt cotton (Gossypium hirsutum) as influenced by plant geometry and fertilizer levels. International Research Journal of Natural and Applied Sciences. 3(5): 175-182.

Bhalerao, P.D., Gawande, P.P., Ghatol, P.U and Patil, B.R. 2008. Performance of Bt cotton hybrids for various spacing under rainfed condition. Agricultural Science Digest. 28(1): 54-56.

Brar, A.S., Sarlach, R.S., Sohu, R.S and Rathore, P. 2013. Response of American cotton (Gossypium hirsutum L.) genotypes to varying plant densities and graded levels of fertilizers. Society for Plant Research. 26(2): 145-147.

Chen, Dehua, Ye Guoyou, Yang Changquin, Chen, Yuan and wu Yunkang. 2004. Effect after introducing Bacillus thuringiensis gene on nitrogen metabolism in cotton. Field Crop Research. 87: 235-44.

Devraj, Bhttoo, M.S., Duhan, B.S., Kumari, P and Jain, P. 2011. Effect of crop geometry and fertiliser levels on seed cotton yield and nutrient uptake of $\mathrm{Bt}$ cotton under irrigated conditions. Journal of Cotton Research and Development. 25(2) : 176-180.

FAS, 2014. Oilseeds: World Markets \& Trade. Jan. 2014. Available online at http://www.fas.usda.gov/data/oilseedsworldmarkets-and-trade.

Gangaiah, B., Ahlawat, I.P.S and Babu, M.B.B.P. 2013. Response of nitrogen fertilization on $\mathrm{Bt}$ and non-Bt cotton (Gossypium hirsutum) hybrids. SAARC Journal of Agriculture. 11(1): 121-132.

Gomez, K.A., and Gomez, A.A. 1984. Statistical procedures for agriculture research. John Wiley and Sons Publishers, New York. Pp. 357-423.

Jadhav, S.G., Chavan, D.A., Gokhale, D.N and Nayak, S.K. 2015. Influence of plant geometry, growth regulator and nutrient management on performance of $\mathrm{Bt}$ cotton under irrigated condition. International Journal of Tropical Agriculture. 33(2): 1755-1759.

Kairon, M.S., D.B. Laise and M.V. Venugopalam. 2004. Cotton. In: R. Prasad (ed.) Field Crops Production, ICAR, New Delhi, India. Pp. 646674.

Kalaichelvi, K., 2008. Effect of planting geometry and fertilizer levels on weed density and biomass in Bt cotton. Indian Journal of Weed Science. 40(1\&2): 6668.

Krishnaveni, P., Pulla Rao, Ch., Srinivasulu, K., Subbaiah, G and Veera Ragavaiah, R. 2010. Productivity, quality and economics of $\mathrm{Bt}$ cotton hybrids as influenced by plant density. The Andhra Agricultural Journal. 57(4): 326-329.

Madhavi, B., 2016. Impact of high density planting and weed management practices on growth and yield of $\mathrm{Bt}$ cotton. M.Sc. (Ag) Thesis. Professor Jayashankar Telangana State 
Agricultural University, Rajendranagar, Hyderabad.

Manjunatha, M.J., Halepyati, A.S., Koppalkar, B.G and Pujari, B.T. 2010. Yield and yield components, uptake of nutrients, quality parameters and economics of Bt cotton (Gossypium hirsutum L.) genotypes as influenced by different plant densities. Karnataka Journal of Agricultural Sciences. 23(2): 423-425.

Reddy, R.R., and Gopinath, M. 2008. Influence of fertilizers and plant geometry on performance of Bt cotton hybrid. Journal of Cotton Research and Development. 22(1): 78-80.

Sankaranayanan, K., Praharaj, C.S., Narayini, $\mathrm{P}$ and Gopalakrishnan, N. 2011. Growth, yield and quality of Bt cotton (Gossypium hirsutum L.) hybrids under varied planting pattern, NPK levels and seasonal variations. Indian Journal of Agricultural Sciences. 81(9): 871-874.

Shukla, U.M., Khakare, M.S., Bhale, V.M. and Singh, S. 2013. Plant population, nutrient uptake and yield of cotton (Gossypium hirsutum) hybrids as affected by spacing and fertility levels under rainfed conditions. Indian Journal of Agriculture Research. 47(1): 83-88.

Wang, G., Assimwe, R.K and Andrade, P. 2011. Growth and yield response to plant population of two cotton varieties with different growth habits. Arizona cotton report (161). Pp. 6-11.

Watson, D.J., 1957. The physiological basis of variation in yield. Advances in Agronomy. 4: 101-145.

\section{How to cite this article:}

Nagender, T., D. Raji Reddy, P. Leela Rani, G. Sreenivas, K. Surekha, Akhilesh Gupta and Sreekanth, P.D. 2017. Productivity of BT and Non BT Cotton (Gossypium hirsutum L.) Cultivars as Influenced by Plant Geometry and Fertilizer Levels. Int.J.Curr.Microbiol.App.Sci. 6(9): 3208-3217. doi: https://doi.org/10.20546/ijcmas.2017.609.395 